\title{
Pollinator community of sunflower (Helianthus annus L.) and its role in crop reproductive success
}

\begin{abstract}
Wali Muhammad1,2*, Shafqat Saeed ${ }^{3}$, Ammad Ahmad4, Muhammad Yasir Ishfaq ${ }^{5}$, Muhammad Mahtab Anjum ${ }^{6}$ ${ }^{1}$ Pest Warning and Quality Control of Pesticides, Agriculture Department, Government of Punjab, Pakistan

${ }^{2}$ Department of Entomology, Faculty of Crop and Food Sciences, PMAS Arid Agriculture University, Rawalpindi, Pakistan ${ }^{3}$ Institute of Plant Protection, Muhammad Nawaz Shareef (MNS) University of Agriculture, Multan, Pakistan

${ }^{4}$ Department of Entomology, University College of Agriculture and Environmental Sciences, The Islamia University of Bahawalpur, Pakistan

${ }^{5}$ Department of Entomology, Faculty of Agriculture, Gomal University, Dera Ismail Khan, Pakistan

${ }^{6}$ Department of Entomology, Faculty of Agricultural Sciences and Technology, Bahauddin Zakariya University, Multan, Pakistan
\end{abstract}

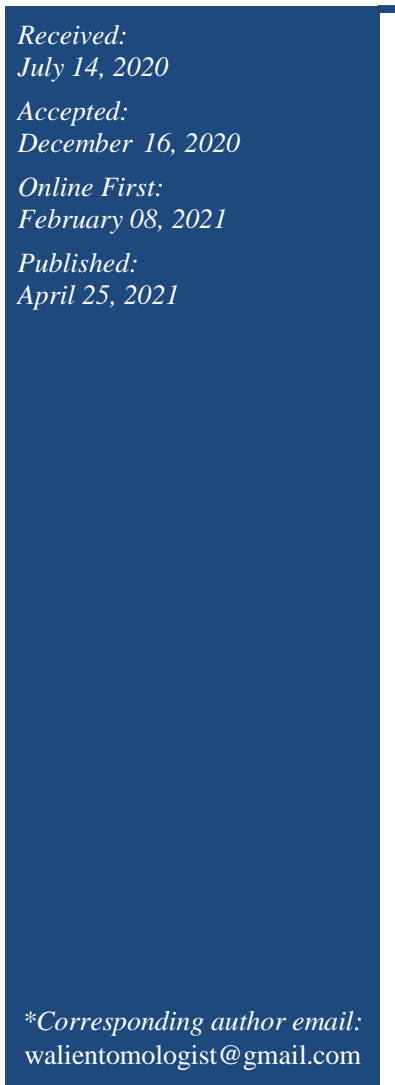

\begin{abstract}
A study was carried out to identify the pollinator community and its role in pollination of sunflower at the research farm of Bahauddin Zakariya University, Multan, Pakistan. The community of pollinators was composed of 14 insect species including eight bee species (Hymenoptera), four fly species (Diptera) and two butterfly species (Lepidoptera). Bees were the most abundant floral visitors. Apis dorsata Fabricius, Xylocopa sp and Megachile sp. were the most abundant among the bees with the highest visitation frequencies i.e. $1.33,0.07$ and 0.06 individuals per head per minute, respectively. The abundant flies included Eristalinus aeneus Scopoli and E. arvorum Linnaeus. The peak visitation activity of pollinators was recorded between 08:00 to 10:00 hrs. Although there was no significant difference in number of seeds per head produced in insect pollinated (open) as compared with, without insect pollinated (caged) heads. However, insect pollination significantly increased the number of healthy seeds, 100 seed weight and germination percentage. As A. dorsata Fabricius was the major pollinator of sunflower, future studies should focus on its conservation for better crop production.
\end{abstract}

Keywords: Sunflower, Pollination, Pollinator community, Reproductive success

\section{How to cite this:}

Muhammad W, Saeed S, Ahmad A, Ishfaq MY and Anjum MM, 2021. Pollinator Community of Sunflower (Helianthus annus L.) and its Role in Crop Reproductive Success. Asian J. Agric. Biol. 2021(2): 202007398. DOI: https://doi.org/10.35495/ajab.2020.07.398

This is an Open Access article distributed under the terms of the Creative Commons Attribution 3.0 License. (https://creativecommons.org/licenses/by/3.0), which permits unrestricted use, distribution, and reproduction in any medium, provided the original work is properly cited.

\section{Introduction}

Terrestrial ecosystems are mainly maintained by mutualistic interactions between animal pollinators and the flowering plants (Nicolson and Wright, 2017).
Pollination is a critical ecosystem service in natural and agricultural systems delivered by animals as 75 percent of flowering plants species require animal mediated pollination (Cayenne and Rebecca, 2003). Pollination is often carried out by animals such as 
insects, birds and bats. Insect are commonly known as the best functioning elements in terms of pollination in terrestrial ecosystem of the world (Klein et al., 2007). By facilitating sexual reproduction, they put positive impact on the yield, quality and genetic stabilization of majority of crop species (Muhammad et al., 2020). Under the worst-case scenario of rapid climate change events, there is a threat of food shortage and economic insecurity especially in the developing countries (Ali et al., 2011). Pollinators, especially the wild and managed bees can contribute significantly in this regard as they contribute 62 percent of the total global food supply (Stein et al., 2017).

Sunflower (Helianthus annuus L.) is an economically important oilseed crop (contributes $32 \%$ of domestic edible oil production) and is cultivated under variety of environmental conditions due to its resistance to adverse weather conditions, crop rotation, intercropping options and succession in seedproducing regions (Porto et al., 2007). There are several species of wild bees helping sunflower pollination but Bombus haemorrhoidalis Smith is most reported specie helping sunflower pollination (Sheikh et al., 2014). Honeybees have been reported as very important pollinators of sunflowers across the world (Andrada et al., 2004; Mehmood et al., 2018). They support better seed and oil content production by supporting fertilization process (Morgado et al., 2002; Nderitu et al., 2008). Studies conducted in Pothwar area of Pakistan have shown that wild bees and honeybees are helpful in quality seed development in canola crop (Razzaq et al., 2019). However, widespread application of insecticides and destruction of nesting sites of honeybees is leading to decline in their populations and ultimately hampering sunflower yield (DeGrandi-Hoffman and Martin, 1995; Santana et al., 2002). Pollinator community is attracted towards flowering plants based on numerous factors including nectar sugars, corolla length and pollen quality. Studies have shown that sunflower pollinators are attracted to the cultivars having higher amounts of nectar sugar (Mallinger and Prasifka, 2017).

Foraging activity of pollinators is very important in determining reproductive performance of various plants (Wubie et al., 2014; Yao et al., 2006; Said et al., 2017). Foraging activity including visitation rate, visitation frequency and stay time on flower is greatly influenced with the weather conditions. Wild bees are the most abundant group of flower visitors than flies in the areas having natural vegetation (Saeed et al., 2017; Liu et al., 2019; Bartual et al., 2018). Honeybees are most dominant pollinators in Pothwar region of Pakistan comprising of $78 \%$ pollinator community in sunflower season. Among the honeybee's group of pollinators, Apis mellifera was reported as most abundant specie (Rasheed et al., 2015; Aslam and Awan, 2000; Mehmood et al., 2018; Razzaq et al., 2019; Perrot et al., 2019). Sajjad et al. (2017) have reported Apis dorsata and. A. florea as the most abundant pollinators of sunflower in Multan, Pakistan. Present study was planned to evaluate the role of pollinators' community in sunflower pollination in terms of different yield attributing components and seed germination. The diurnal pollination activity was also recorded.

\section{Material and Methods}

The study was carried out at the research farm of Bahauddin Zakariya University, Multan, Pakistan from March to June, 2015. The study area was an intensively managed agricultural landscape with a small tree plantation at distance of one kilometer in East. Data recording was started when $20 \%$ sunflower plants were at flowering stage. Data was recorded continuously until about $80 \%$ seed setting occurred. At $50 \%$ flowering stage, ten plants were randomly tagged to see the effect of open pollination. Other 10 plants were covered before the opening of flowers with mesh bags to exclude insect pollinators for insects. Biweekly observations of flower-visiting insects were made from $15^{\text {th }}$ of April to $15^{\text {th }}$ of May. In each census, 20 plants were randomly selected and each plant was observed for 15 minutes for number of individuals of different floral visitors.

Two parameters of floral visitor assemblage were derived from the data i.e. overall abundance (total number of individuals of each floral visitor in all the censuses) and visitation frequency (mean number of individuals of each floral visitor on single plant during one minute of interval). Some of morphologically distinct floral visitors were also caught by aerial net for later identification. Insects were identified to the lowest possible taxonomic level. The data were recorded six times in each observation day i.e. 8:00, 10:00, 12:00, 14:00, 16:00 and 18:00 hrs.

The heads of open and caged plants were harvested upon maturity. The yield attributing components were recorded as the weight of heads, diameter of head $(\mathrm{cm})$, number of healthy and unhealthy (wrinkled) seeds per head, seed weight per head and germination percentage. 
The weight of head and weight of seeds per head was measured using electronic balance. The diameter of head was recorded by using simple scale. Number of unhealthy seeds per head was measured manually. Germination percentage was determined by selection of 100 healthy seeds each from open and caged heads. These seeds were soaked for 6 hours and then sown in moist sand containing petri dishes. These petri dishes were placed under shade showered on daily bases with tap water using a hand sprayer. Germinating plants were counted on daily basis for a week until germination process stopped. The data regarding yield attributing components were compared between open and caged treatments using T-test at alpha 0.05 .

\section{Results}

The generated data revealed that the floral visitors of sunflower observed were belonged to five families in three orders i.e. Syrphidae in Diptera, Danaidae in Lapidoptera and Apidae, Halictidae and Megachilidae in Hymenoptera.

Overall, insects belonging to Hymenoptera were the most abundant pollinators of sunflower crop. Among Hymenoptera, the giant wild honeybee (Apis dorsata) was the most abundant floral visitor with 839 individuals (Table 1). The maximum visitation frequency of 1.33 individuals /flower/minute was also observed for A. dorsata (Table 1).

Foraging behavior was seemed to be greatly affected by the weather factors along the day. The peak abundance of pollinators was observed at the start of the day (8:00 hrs.) which declined gradually up to 4:00 hrs. Again, it got an increase at 6:00 hrs. but less than half of the morning abundance (Figure 1).

There was no significant difference between head weight, head diameter and number of seeds per head in open and caged pollinated treatments. However, open pollinated heads (insect pollinated) showed significantly less number of unhealthy seeds (169.6 \pm 48.5$)$, higher 100 seed weight $(6.61 \pm 0.57 \mathrm{~g})$ and higher germination percentage $(42.8 \pm 1.52 \%)$.

Table-1. Insect species visiting sunflower flowers along with their total abundance, visitation frequency and foraging behavior

\begin{tabular}{|c|c|c|c|c|}
\hline Order & Family & Genus/Species & $\begin{array}{l}\text { Overall } \\
\text { indance }\end{array}$ & $\begin{array}{c}\text { Visitation } \\
\text { frequency } \\
\text { (Individuals } \\
\text { /flower/minute) }\end{array}$ \\
\hline \multirow{4}{*}{ Diptera } & \multirow{4}{*}{$\begin{array}{c}\text { Syrphida } \\
\text { e }\end{array}$} & Eupeodes corollae & 4 & 0.006 \\
\hline & & $\begin{array}{l}\text { Ischiodon } \\
\text { scutellaris }\end{array}$ & 8 & 0.01 \\
\hline & & Eristalinus arvorum & 6 & 0.009 \\
\hline & & Eristalinus aeneus & 11 & 0.02 \\
\hline \multirow{2}{*}{ Lepidoptera } & \multirow[t]{2}{*}{ Danaidae } & Danaus chrysippus & 10 & 0.02 \\
\hline & & Eurema hecabe & 8 & 0.01 \\
\hline \multirow{8}{*}{$\begin{array}{l}\text { Hymenopter } \\
\mathrm{a}\end{array}$} & \multirow{4}{*}{ Apidae } & Apis dorsata & 839 & 1.33 \\
\hline & & Apis florea & 4 & 0.006 \\
\hline & & Xylocopa sp. & 45 & 0.08 \\
\hline & & Amegilla $\mathrm{sp}$. & 13 & 0.02 \\
\hline & \multirow{3}{*}{$\begin{array}{c}\text { Halictida } \\
\text { e }\end{array}$} & Lasioglossum sp.1 & 13 & 0.02 \\
\hline & & Lasioglossum sp. 2 & 26 & 0.04 \\
\hline & & Halictus sp. & 20 & 0.03 \\
\hline & $\begin{array}{c}\text { Mehachil } \\
\text { idae }\end{array}$ & Megachile sp. & 44 & 0.06 \\
\hline
\end{tabular}

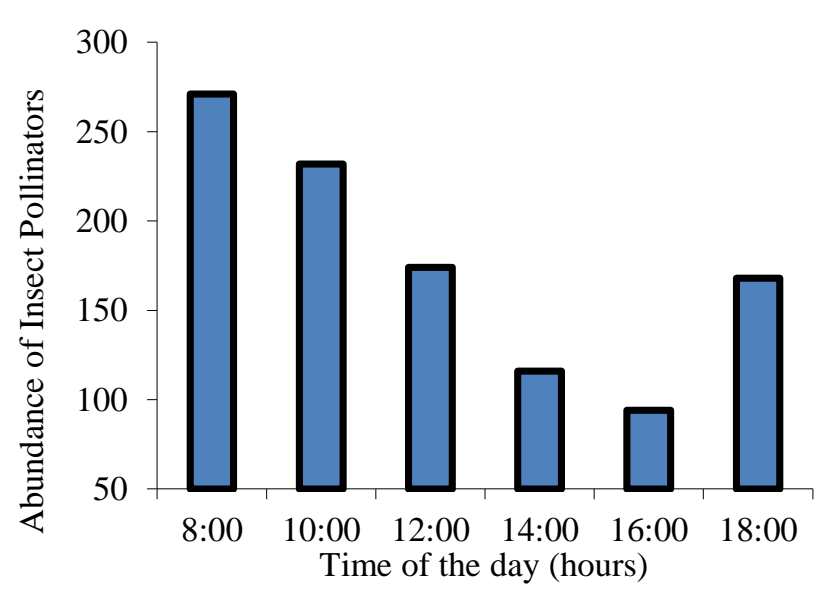

Figure-1. Diurnal abundance trend of floral visitors in sunflower

Table-2. Comparison of yield components resulted from insect pollinated and covered sunflower heads.

\begin{tabular}{|c|c|c|c|c|c|c|c|}
\hline \multicolumn{2}{|c|}{ Yield components } & $\begin{array}{c}\text { Head weight } \\
\text { (g) }\end{array}$ & $\begin{array}{c}\text { Head } \\
\text { diameter }(\mathrm{cm})\end{array}$ & $\begin{array}{c}\text { No. of } \\
\text { Seeds/head }\end{array}$ & $\begin{array}{l}\text { No. of unhealthy } \\
\text { seeds/head }\end{array}$ & $\begin{array}{l}100 \text { Grain } \\
\text { Wt. (g). }\end{array}$ & $\begin{array}{c}\text { Germination } \\
(\%)\end{array}$ \\
\hline \multicolumn{2}{|c|}{ Insect pollinated } & $144 \pm 24.24$ & $18.6 \pm 1.25$ & $1501.4 \pm 19.42$ & $169.6 \pm 48.5$ & $6.61 \pm 0.57$ & $42.8 \pm 1.52$ \\
\hline \multicolumn{2}{|c|}{ Self-pollinated } & $141.3 \pm 30.33$ & $16.8 \pm 1.72$ & $1479.1 \pm 121.32$ & $364.4 \pm 36.2$ & $5.1 \pm 0.31$ & $21.4 \pm 3.12$ \\
\hline \multirow{4}{*}{ 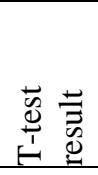 } & Difference & 2.746 & 1.873 & -22.310 & -194.807 & 1.905 & 21.433 \\
\hline & $\mathrm{t}$ (Observed) & 0.071 & 0.877 & -0.182 & -3.218 & 2.907 & 6.169 \\
\hline & ||$t \mid$ (Critical) & 2.306 & 2.306 & 2.306 & 2.306 & 2.306 & 2.306 \\
\hline & p-value & 0.945 & 0.406 & 0.860 & 0.012 & 0.020 & 0.000 \\
\hline
\end{tabular}




\section{Discussion}

Among the assorted flower visitors of sunflower in current study, Apis dorsata was recorded as the most abundant pollinator. In the sub-tropical climatic conditions of south Punjab, Pakistan, A. dorsata plays a significant role in successful seed production of sunflower, which not only improves the quality of grains but also results in higher yield (Said et al., 2018; Said et al., 2017). The arrangement of flowerets in the sunflower i.e. layer of non-productive zygomorphic ray florets at the edge of the capitulum and several productive actinomorphic disk flowerets in the center, serves as a visual signal that entices honeybees (Wojtaszek and Maier, 2014).

Native bees including wild honeybees have also been reported as important pollinators of many other crops in the study region (Muhammad et al., 2020; Bartual et al., 2018; Mehmood et al., 2018). Although other solitary bees were not as abundant as honeybees but they supplement the overall pollination of sunflower by creating interspecific behavioral interaction which ultimately increase the per-visit efficacy of honeybees (Fründ et al., 2013; Greenleaf and Kremen, 2006; Liu et al., 2019). Pollination efficiency of honeybees can increase five times when they pollinate in aggregation with wild bees, thus a little diversity and abundance of wild bees can increase the crop pollination as well as crop yield (Greenleaf and Kremen, 2006). The similar results were presented by Mehmood et al. (2018), who reported that maximum activity was observed in morning hours as shown in figure 01 .

There was no significant difference observed in head weight, diameter and number of seeds per head among open and caged flowers. Head weight and its diameter are independent of the pollinators' visitation as these are mainly the varietal characters and some agronomic practices (Balalić et al., 2016; Liu et al., 2019). Moreover, sunflower also exhibits some degree of wind and self-pollination, but their role has never been quantified (Degrandi-Hoffman and Chambers, 2006; Perrot et al., 2019).

In the present study, less number of unhealthy seeds, higher seed weight and seed germination was recorded in open pollinated heads. This finding is comparable with the result of Chambó et al. (2011) who recorded $43 \%$ higher seed yield from sunflower plants that were visited by insects' pollinators compared with plants circumscribed to pollinators. Similar experiment was also performed by Nderitu et al. (2008) who also recorded 53\% more seed yield from sunflower plots which were visited by insects' pollinators as compared to plots from where pollinators were excluded.

\section{Conclusion}

Based on results of current study it was concluded that sunflower attracts a rich fauna of insects which is mostly comprises of honeybees. Insect pollination does not increase the number of seeds per head; however it increases number of healthy seeds, seed weight and germination percentage. Therefore pollinators (honeybees), not only improve the yield of sunflower but also improve the quality of seeds. Future studies should be focused on conservation of honeybees for better crop production.

\section{Disclaimer: None. \\ Conflict of Interest: None. Source of Funding: None.}

\section{References}

Ali M, Saeed S and Sajjad A, 2011. In search of the best pollinators for canola (Brassica napus L.) production in Pakistan. Appl. Entomol. Zool. 46:353-361 DOI: 10.1007/s13355-011-0051-0

Ali S, Liu Y, Ishaq M, Shah T, Ilyas A and Din IU, 2017. Climate change and its impact on the yield of major food crops: Evidence from Pakistan. Foods. 6(6):39.

Andrada A, Valle A, Pablo P and Gallez L, 2004. Pollen and nectar sources used by Honeybee colonies pollinating Sunflower (Helianthus annuus) in the Colorado River Valley, Argentina. Bull. Bot. Soc. Argen. 39 (1-2): 75 - 82.

Aslam M and Awan NA, 2000. Melittophily and Aphidophagy Found on Sunflower (Helianthus annuus Linnaeus) (Compositae) Genotypes. Pak. J. Biol. Sci. 3: 2251-2252.

Balalić I, Crnobarac J, Jocic S, Miklic V, Radic V and Dusanic V, 2016. Variability of head diameter in sunflower hybrids depending on planting date. Genetika, 48(3): 983 - 990.

Bartual AM, Bocci G, Marini S and Moonen AC, 2018. Local and landscape factors affect sunflower pollination in a Mediterranean agroecosystem. PloS one. 13(9):0203990.

Cayenne E and Rebecca EI, 2003. Linking Pollinator Visitation rate and Pollen Receipt. Am. J. Bot. 90(11):1612-1618. 
Chambó ED, GarciaRC, Oliveira and Duarte-Júnior JB, 2011. Honey bee visitation to sunflower: effects on pollination and plant genotype. Sci. Agric. 68(6): 647-651.

DeGrandi-Hoffman G and Chambers M, 2006. Effects of honey bee (Hymenoptera: Apidae) foraging on seed set in self-fertile sunflowers (Helianthus annuus L.). Environ. Entomol. 35(4):1103-1108.

DeGrandi-Hoffman G and Martin JH, 1995. Does a honeybee (Apis mellifera) colony's foraging population on male-fertile sunflowers (Helianthus annuus) affect the amount of pollen on nestmates foraging on male-steriles? J. Apic. Res. 34(3):109114.

Fründ J, Dormann CF, Holzschuh A and Tscharntke $\mathrm{T}$, 2013. Bee diversity effects on pollination depend on functional complementarity and niche shifts. Ecol. 94: 2042-2054.

Greenleaf SS and Kremen C, 2006. Wild bees enhance honeybee's pollination of hybrid sunflower. Proc. Natl. Acad. Sci. India. Sect. B. Biol. Sci. 103(37): 13890-13895.

Klein AM, Vaissière BE, Cane JH, Steffan-Dewenter I, Cunningham SA, Kremen C and Tscharntke T, 2007. Importance of pollinators in changing landscapes for world crops. P. Roy. Soc. Lon. B. Biol. 274: 303-313.

Liu Q, Xu P, Yan K and Guo Y, 2019. Pollination Services from Insects in Homegardens in the Chengdu Plain will be Confronted with Crises. Sustainability. 11(7): 2169.

Mallinger RE and Prasifka JR, 2017. Bee visitation rates to cultivated sunflowers increase with the amount and accessibility of nectar sugars. J. Appl. Entomol. 141(7): 561-573.

Mehmood K, Naeem M, Ahmad M and Butt SJ, 2018. Diversity of sunflower insect pollinators and their foraging behavior under field conditions. Uludag Bee. J. 18(1): 14-27.

Morgado LN, Carvalho CF, Souza B and Santana MP, 2002. Fauna of bees (Hymenoptera: Apoidea) on sunflower flowers, Helianthus annuus L., in Lavras, Minas Gerais. Cienc. Agrotec. Brazil. 26(6): 1167-1177.

Muhammad W, Ahmad M and Ahmad I, 2020. Pollination Behavior of Cotton Crop and Its Management, pp. 163-176. In: Ahmad S, Hasanuzzaman M. (eds) Cotton Production and Uses. Springer, Singapore

Nderitu J, Nyamasyo G, Kasina M and Oronje ML, 2008. Diversity of sunflower pollinators and their effect on seed yield in Makueni District, Eastern Kenya. Span. J. Agric. Res. 6(2): 271-278.

Nicolson SW and Wright GA, 2017. Plant-pollinator interactions and threats to pollination: perspectives from the flower to the landscape. Funct. Ecol. 31: 22-25. doi:10.1111/13652435.12810

Perrot T, Gaba S, Roncoroni M, Gautier JL, Saintilan A and Bretagnolle V, 2019. Experimental quantification of insect pollination on sunflower yield, reconciling plant and field scale estimates. Basic. Appl. Ecol. 34: 75-84.

Porto WS, Carvalho CGPD and Pinto RJB, 2007. Adaptability and stability as selection criteria for sunflower genotypes. Pesqui. Agropecu. Bras. 42(4): 491-499.

Rasheed MT, Inayatullah M, Shah B, Ahmed N, Khan A, Ali M, Ahmed S, Junaid K, Adnan M and Huma Z, 2015. Relative abundance of insect pollinators on two cultivars of sunflower in Islamabad. J. Entomol. Zool. Stud. 3: 164-165.

Razzaq A, Abbasi KH, Jamal M, Aslam A, Malik K and Ullah MA, 2019. Evaluation of Pollination by Honeybee (Apis Mellifera L.) on Canola (Brassica Napus L.) Produce. Biomed. J. Sci. Tech. Res. 22(4): 16833-16836.

Saeed S, Bashir MA, Khan KA, Sajjad A, Alvi AM, Atta S and Ansari MJ, 2017. Assemblage of pollinator communities in four widely isolated nature reserves of southern Punjab, Pakistan. Saudi. J. Biol. Sci. 26(4): 860-865.

Said F, Inayatullah M and Hussain A, 2017. Studies on visitation pattern of honeybee (Hymenoptera: Apidae) and its impact on the yield and oil contents of sunflower (Helianthus annuus L.) seed in Peshawar valley, Pakistan. Pak. J. Zool. 49(3): 943-949.

Said F, Jalal F, Imtiaz M, Khan MA and Hussain S, 2018. Foraging behavior of the giant honeybee, Apis dorsata F. (Hymenoptera: Apidae) in sunflower (Helianthus annuus L.) at Peshawar District of Pakistan. Pure. appl. biol. 7(3): 11151121.

Sajjad A, Ali M and Saeed S, 2017. Yearlong association of Apis dorsata and Apis florea with flowering plants: planted forest vs. agricultural landscape. Sociobiol. 64(1): 18-25.

Santana MP, Carvalho CF, Souza B and Morgado LN, 2002. Bees (Hymenoptera: Apoidea) visiting bean flowers, Phaseolus vulgaris L., in Lavras and Ijaci, 
Minas Gerais. Cienc. Agrotec. Brazil. 26(6): 1119-1127.

Sheikh UAA, Ahmad M, Imran M, Nasir M, Saeed S and Bodlah I, 2014. Distribution of bumblebee, Bombus haemorrhoidalis Smith, and its association with flora in lower Northern Pakistan. Pak. J. Zool. 46(4): 1045-1051.

Stein K, Coulibaly D, Stenchly K, Goetze D, Porembski S, Lindner A and Linsenmair EK, 2017. Bee pollination increases yield quantity and quality of cash crops in Burkina Faso, West Africa. Sci. Rep. 7(1): 17691.

Wojtaszek JW and Maier C, 2014. A Microscopic Review of the Sunflower and Honeybee Mutualistic Relationship. Int. J. Agric. Sci. 4(5): 272-282.

Wubie A, Bezabeh A and Kebede K, 2014. Floral phenology and pollen potential of honeybee plants in North East dry land areas of Amhara Region, Ethiopia. IOSR. J. Agric. Vet. Sci. 7(1): 36-49.

Yao YF, Bera S, Wang YF and Li CS, 2006. Nectar and pollen sources for honeybee (Apis cerana Fabr.) in Qinglan mangrove area, Hainan Island, China. J. Integr. Plant. Biol. 48(11), 1266-1273.

\section{Contribution of Authors}

Muhammad W: Planned and conducted the trials Saeed S: Approved and provided funding and research area

Ahmad A: Planned the data sheets and conducted statistical analysis

Ishfaq MY: Recoded data and write up

Anjum MM: Recoded data and write up 